\title{
Plasma Cell Myeloma by DS Stage
}

National Cancer Institute

\section{Source}

National Cancer Institute. Plasma Cell Myeloma by DS Stage. NCI Thesaurus. Code C139008.

A header term that refers to the staging of plasma cell myeloma according to the Durie/Salmon staging system. 